these cells upon which life depends. Small po- weight. Moreover, when these men leave off tations would not make so marked change, and their drinking and return to their feet and senses, hence be difficult to detect; yet the functions of they would spry around and do more than usual these cells are known to be depreciated by even small doses.

Now, how comes it that alcohol shrinks the blood-cells, the kittens' bladders, etc.? It is by peculiar osmosis; for it has no attraction for the substance of the animal membrane, at least no attraction as compared with water, hence the water readily passes through the membrane while the alcohol does not; this affinity or otherwise for the membrane being a powerful factor governing osmosis. ${ }^{3}$

Not only does alcohol affect the globules in this peculiar way but it exerts the same kind of influence on moist animal tissues everywhere - the brain, nerves, tendons, muscles-drawing out their water, shrinking, hardening, stiffening them till the hard drinker in middle life, is advanced to the decrepitude of old age.

Looking then upon the shrunken condition of the blood-cell, does anyone require me to say, "They cannot do their work?"

Dr. Hammond was correct in his observation that they did not cast out so much dead waste, in the form of urea and carbonic acid. With the fact of the peculiar action of alcohol on the bloodcells before us, this is just what he had a right to expect. Indeed it could not have been otherwise. As surely as shadow follows upon light, so surely must a depreciation of the character of the globules be attended with a depreciation of their functions in elimination. But his construction of the gain in weight by the liquor into conservation of tissue, is the sublimation of theory: As though by putting a dam across a running brook, we stop the springs which supply the water! As though by getting the ash-men drunk and, finding less ashes going to the dump, we conserve the people's fuel! As though by getting the undertakers off their legs by brandy and because fewer bodies go into the cemetery, therefore, the brandy conserves the health of the city! The blood-globules are the ash-men and the undertakers of the body and can no more do their work when drunk than drunken men can do theirs.

Again, let this use of brandy by the ash-men and undertakers go on for any length of time, what then? There would be an outcry because of obstructed furnaces, and the city would reek from end to end with the dead in our homes and along our streets. Just so every body knows how foul is the breath and the exhalations from every pore of the body of persons who heavily indulge for a time. They get overflowing full of the dead waste which has accumulated within.

Their's is not the smell of living tissue. Their faces swell, their bodies bloat and increase in

5ee this more largely explained in "Alcohol Inside Out." the next few days till the city was clean and sweet again. Exactly this is what all observers notice - more excretion after the liquor is withdrawn for a time, till the wastes are removed and the body and breath lose their stench, the bloating goes down, the face and eyes become clear once more. But how about Dr. Hammond's $7 \frac{1}{5}$ ounces? Was it not of this sort of tissue, to disappear as soon as it came?

In the face of this series of facts, who can believe in the theory of conservation of living tissue, rather than in the obstructed elimination of dead waste - waste of tissue and combustion which health demands should be thrown out? The retention of such is a positive hindrance to normal physiology-as inimical to good health as an obstructed stove to a good fire.

Depression of the globules depresses every other vital function-heat, physical and mental force. Dr. Hammond admits that he was not himself as well, and was not inclined to exertion while taking his drams. Considering then the theory of conservation of tissue untenable and contrary to fact - the effect of alcohol on the sen. sitive blood-globules and their function explaining all the observations - the time has come for us to change our practice to accord with facts or the legitimate, rational deductions from them.

This action of alcohol on the blood-globules opens up a wide field for therapeutics, both as to diet and medicine, which should appeal to thoughtful consideration. ${ }^{6}$

SOME SPECIAL REASONS WHY THE LAPAROTOMIST SHOULD CONSIDER THE MEDICO-LEGAL ASPECTS OF ABDOMINAL SURGERY.

Read in the Section of Medical Jurisprudence at the Forty-first Annual Meeting of the American Medical Association, at Nashville, Tenn., May, I89o.

BY HENRY O. MARCY, A.M., M.D., LI.D., OF BOSTON, MASS.

The evidence that the question under discussion is many-sided is shown by the different titles which the distinguished specialists have chosen who are announced to furnish, to-day, contributions upon the medico-legal aspects of abdominal surgery. I have selected a very minor subdivision of the topic, to which I propose to confine my remarks, to wit: namely, the opinions which the great body politic of the profession hold in relation to the justifiability of abdominal operations in general, and the influence which such opinions exert, as commonly expressed in everyday practice. 
Twenty years have elapsed since I became a special student of abdominal surgery. Leaders of the profession at that time in New England, without doubt with the most disinterested motives, earnestly gave me warning that if I allowed myself to be known as having special interest in this department of professional work, as viewed from the surgical aspect, it would be fatal to my ambitions as a young practitioner, and justly put me beyond the pale of general medical support. The argument was enforced by the citation of the experience of Sir Spencer Wells, who, not long prior to this period, had visited Boston, with the statement that many leading members of the profession in our goodly city had refused presentation to this distinguished surgeon, upon the ground that the course he was pursuing in the treatment of abdominal tumors was entirely unwarranted and unjustifiable. They emphasized the argument by citing the fact that Drs. Gilman Kimball, of Lowell, and Horatio R. Storer, of Boston, then, and for a long time after, the two leading specialists of New England, were looked upon with general distrust, without the hope of general professional recognition and approval. The only reply to the argument, that modern surgical procedures rendered warrantable a large class of operations hitherto considered improper, was met with the blunt statement " that you will kill your patients, as we have done, and you should profit by our experience."

When, scarcely more than a decade ago, I made application to one of the leading hospitals of Boston for a small ward to be devoted exclusively to the surgical diseases pertaining to women, the answer was, "It has not yet come to the knowledge of the Trustees that there is any demand for the recognition or relief of this supposed class of sufferers."

At about the same date, in another of the gen. eral hospitals of Boston, when it was proposed to appoint as a special surgeon in the department of diseases of women a man who is known wherever surgery is read, the entire staff threatened resignation, and caused the withdrawal of the nomination. It would not be difficult to multiply evidence of this character and show that the conservatism of the medical profession in America, especially in New England, had in reality been one of the greatest obstacles in the way of modern progress and reform, notwithstanding we now recount with pride that to American surgeons, under the leadership of a small number of men, whose fame will remain immortal, is accorded the high honor of establishing upon a sure basis gynesic surgery.

In the rapid progress of events the pendulum of public opinion has, in a measure, swung in the opposite direction, especially as represented by the younger and better educated class of practitioners throughout the country. Many of the seniors, however, hold in ill-disguised contempt the teachings of modern surgery, and do not fail to improve the opportunity, whenever offered, of expressing their opinions in forcible language, and this, unfortunately, more often to the laity. Instances of this are not wanting in the everyday experience of most of us. Some time since a prominent member of the profession, claiming to be a surgeon, declared emphatically " that antiseptic surgery was a nonsensical delusion, but that so much had been said upon the subject he found himself obliged to use carbolic acid, though he hated the nasty stuff, lest he should be thought behind the times, and in case anything went wrong with his patients, he should be held accountable to the courts for not having discharged his obligations in a due and just manner."

Within a few days, in consultation where uncertainty exists in the diagnosis of an obscure abdominal tumor, I proposed an exploratory laparotomy, and was met with the reply, "If you do it you will kill your patient"-the opinion of a surgeon who has made special repute as a medical expert. I offer, in further illustration, the copy of a letter written by a senior member of the profession, and a medical teacher, to a lady who, after having been for a long time under his care without improvement, wrote him that she purposed to change physicians and seek surgical relief. After she obtained from me the opinion that her sufferings, in a large measure, were dependent upon a glandular endometritis following abortion, and that curetting was advised, she communicated my opinion by letter, and received the following reply:

BosTon, Sept. 30, I889.

Dear Madam:-Before you have the inside of your womb scraped out, make your will, etc. It is not a safe operation, and it is quite singular that other eminent doctors have not done it. I will bet $\$ I, 000$ it won't cure you. Of course you can have it done if you wish.

$$
\text { Yours truly, }
$$

Notwithstanding such forcible advice the minor operation was performed with satisfactory results. Differences of professional opinion should be expressed freely without reservation on all proper occasions, the most earnest criticism upon all doubtful subjects should be thoughtfully made, and reasons for the faith that is in you should be given. The border lines of our knowledge should ever be kept clearly defined. A half truth is oftentimes more dangerous than an error, and, when stated loosely, is sure to come home to discomfit its advocate. The patient has a legal right to demand from his physician only average, reasonable, prudent attention and care, be it medical or surgical.

The specialist, however, assumes a somewhat different relation to his client, who has a right to demand from him the best service which the subdivision of his art can render. The abdominal surgeon is a specialist, in a division of his work, 
calling for the highest skill, the issues of which are fraught with the greatest dangers. Unlike many of the problems confronting the general surgeon, the unknown factors of the equation must often be expressed by more than $x$ and $y$, and when rendered in known terms, demand fertility of resource and promptness of action as in no other branch of surgery. He who is most experienced ofttimes has the greatest misgivings and is harassed with painful doubts as to his best course of action, not unlike the experienced general in the field who necessarily contends with disadvantages incident upon the lack of knowledge of the force and position of his enemy. Like him, he is most successful when promptitude of action is enforced with boldness, courage and caution, the details of which should be as familiar to him as the movements of disciplined troops or the ritual of a church service.

However, like an official, high in office, where there are great responsibilities, attendant upon the discharge of duty, the surgeon is ever open to public criticism, oftentimes most forcibly expressed by those who least comprehend the situation, or have knowledge of the subject.

Viewed from the medico-legal standpoint, abdominal surgery has little to fear except from ignorance on the part of him who practices and of him who criticises. It is the duty of the specialist, in his department, to teach the general profession, in a simple and clear manner, the outline at least of the fundamental factors, upon which are based the measures of surgical relief, although he may not be asked to trace them in their ever-varying kaleidescopic pattern, as presented in every day practice. Then, and not till then, will the undertone of professional criticism be corrected, to which source may too often be traced the discontent which arises in the mind of the sufferer, and causes him oftentimes to believe that he has been the victim of mal-practice.

Entertaining such an opinion and nursing generally imaginary wrongs, he seeks legal counsel. Listening to a one-sided story, with the thought of prospective fees, the attorney is willing to commence suit, under the encouragement of what Dr. X. has said in criticism, with the statement that it is probable Dr. A. will compromise a settlement rather than be at the trouble and damage incident upon a public trial. Such cases are not rare, and the attorney is right in the supposition that the surgeon is especially sensitive in regard to his reputation, who willingly compromises to avoid notoriety. Thus a species of black-mailing has developed in all the great centres of population.

A noteworthy illustration is furnished in the late experience of our friend, Dr. William L. Baker, of Boston, several points of which case are worthy of comment. For that which seemed to Dr. Baker good and sufficient reason, he ad- vised in the case of a fever sufferer, the removal of the ovaries and tubes. After a careful explanation of the condition and reasons, she was admitted into a charity hospital, and before the operation signed an agreement assenting thereto and holding the doctor harmless of the results. Recovery followed, and, in due time the patient was discharged. Sometime later, there developed in the line of the abdominal wound, a ventral hernia, which at the time she consulted me, was fist-size. Having been sent to my hospital by a wealthy and distinguished gentleman who had become interested in her condition. I advised her to return to Dr. Baker for further treatment, but she expressed a desire to be under my care for the particular condition which caused her present suffering. However, before completing arrangements for operation, it transpired that it was her purpose to secure my opinion, as to the exercise of proper skill and judgment at the former operation, she stating incidentally, that she had consulted one or two other surgeons, well known to me, who had considered the results of the operation questionable. Here the interview ended. Sometime later I was requested to appear in her behalf, as an expert, with the statement that a suit had been entered against the hospital and Dr. Baker for large damages. This invitation I promptly declined. By such adroit measures the prosecution sought to obtain expert testimony, and it was only after three long-continued and expensive trials, subjecting Dr. Baker to a large expenditure of money, vexation of spirit, and loss of time, that he was acquitted of blame. It was held by the court that the written agreement, entered upon prior to the operation was not in itself sufficient; the plaintiff claiming that she did not have the proper understanding of the character of the operation, and its possible attendant dangers and results. Although such an agreement is considered by many as a proper precautionary measure, it may, perhaps be questioned, if in some instances at least, it might not raise doubt and distrust in the mind of the patient, reasoning that the doctor himself was not quite clear in the premises, and thus sought to throw the burden of responsibility of doubt upon the sufferer, which he himself should justly bear. This construction at least might be placed upon it by the average juryman, enforced, as it is sure to be, by the sympathetic plea of the eloquent attorney.

I have never deemed it wise to ask it in my own experience. I understand that in some of the large public hospitals of Massachusetts, there is an incorporating clause that any person seeking the advantages of treatment therein, is debarred from legal redress from either the corporation or attendant physician or surgeon.

I cannot doubt that this is a wise, precautionary measure. I suppose we would all agree that 
an operation of such major importance as a laparotomy should be undertaken only after a careful consultation with one or more surgeons, and that in the presence of friends and competent witnesses, the measures determined upon should be carefully explained in regard to the dangers involved and possible subsequent contingencies, even if the hoped-for result follows, and praise is justly awarded the skillful operator, the lesson of thoughtful prudence will not be lost, but on the other hand, be of great value to the operator, adjudged considerate as well as skillful. In the advent of disaster, it will prevent unjust criticism, and furnish our best protection in defense before the courts.

When doubts arise as to the advisibility of operative interference, these should be clearly stated to the patient and friends, the operation should be distinctly classed as permissive, rather than advised, and after a proper explanation of all its details, the final decision should be left to the sufferer and her friends, and not determined by the surgeon, or performed without their knowledge and full consent.

With such precautions properly enforced, there is little liability of legal complications, following operations in the hands of skillful surgeons. But it must never be forgotten that the first duty of the expert is to carefully consult with and secure if possible, the distinct approval and cooperation of the attending physician or physicians. By such a course professional jealousies are, best of all, allayed, interests harmonized, and coöperation for an honorable protection secured.

\section{THE PATHOLOGY AND TREATMENT OF SYCOSIS.}

Read in the Section of Dermatology and Syphiligraphy at the Fortyfirst Annual Meeting of the American Medical Association, at Nashville, Tenn., May, 1800.

BY JOHN V. SHOEMAKER, A.M., M.D., OF PHILADELPHIA, PA.

Pathology.-In order clearly to comprehend the pathology of sycosis it is of advantage to consider the structure of hair, the mode of its growth and nutrition.

Hair is a modification of the epithelial layer of the integument. The root of each hair is lodged in a little pit called the hair follicle. The follicle descends through the substance of the skin into the subcutaneous connective tissue. Its orifice is shaped like a funnel, the narrower and lower end of the funnel being known as the neck. Below the neck the follicle widens and terminates in a bulbous expansion. The proper wall of the hair follicle belongs to the corium and is divided into three layers: an outer, a middle and an internal. The outer is the thickest and consists of connective tissue fibres disposed parallel to the long axis of the follicle. It supports a small artery and vein and nerve fibres.

The middle layer contains smooth muscle cells. The inner layer is structureless and transparent and is continuous with the basement membrane of the corium.

A small oval or pear-shaped body projects into the cavity of each follicle. This body is called the hair papilla, is composed of connective tissue fibres and corresponds to the other papillæ of the corium. It is continuous with the outer or fibrous layer of the follicle and contains, according to Biesiadecki, two minute arteries, two or more veins and medullated nerve fibres. Its upper surface, which projects into the bottom of the follicle, is covered by the lining membrane of the follicle. This lining membrane is formed by cells derived from the deeper layers of the cuticle.

The lower portion of the root of the hair expands to form the hair bulb which rests upon and embraces the papilla. The bulb is composed of cells which resemble those of the rete malpighii or stratum mucosum, the lowest of the four epithelial layers.

The root and shaft of a hair consists of a medullary substance and a cortical substance, invested by the hair cuticle. The latter is formed by a single layer of non-nucleated hyaline scales which overlap each other. External to the hair cuticle are found an internal and an external root-sheath. The inner root-sheath is continuous with the stratum corneum or external layer of the epiderm. The external root-sheath is simply another name for the internal layer or epithelial lining of the hair follicle, and is derived from the rete malpighii or stratum mucosum.

It will thus be seen that the nutrition of the hair must depend upon the follicle in which it is lodged and especially upon that portion of the follicle called the papilla. The papilla, however, is but an expansion of the outer layer of the hair follicle and the vessels which surround the follicle and those which enter the papilla are in direct communication. A basement membrane is all that intervenes between the vascular papilla and the bulb of the hair. The hair bulb contains columnar and polybedral cells, united by cement substance. These cells resemble those of the stratum mucosum, are continuous with those and with the outer root-sheath which is, as I have said, an inversion of the stratum mucosum or a dipping downward of that layer in order to line the hair follicle. The cells of the bulb actively reproduce themselves, the older ones being constantly forced upward by the development of the lower. As they ascend they become gradually transformed into the component cells of the hair root and shaft. Unna has shown that in certain cases the hair may become detached from the papilla and ascend within the follicle to a point just below the opening of the sebaceous gland, deriving its nutrition meanwhile from the cells of the outer root-sheath. 